\title{
SYNTHESIS, CHARACTERIZATION, THERMAL AND ANTIBACTERIAL STUDY OF A NOVEL SULFONAMIDE DERIVATIVE, $N$-[(E)-PYRIDIN-3-YLMETHYLIDENE]BENZENESULFONAMIDE, AND ITS CO(II), CU(II) AND ZN(II) COMPLEXES
}

\author{
*SAEED-UR-REHMAN, ${ }^{a} A L I A$ FAIZ AND ${ }^{b} R O B I L A N A W A Z$
}

Institute of Chemical Sciences, University of Peshawar, Pakistan

(Received: March 1, 2012 - Accepted: November 15, 2012)

\begin{abstract}
The novel aromatic sulfonamide ligand, $N$-[(E)-pyridin-3-ylmethylidene]benzenesulfonamide (PMBS) was synthesized along with its $\mathrm{Cu}(\mathrm{II}), \mathrm{Co}(\mathrm{II})$ and $\mathrm{Zn}$ (II) complexes of $\mathrm{MLCl}_{2}$ type. The characterization of the complexes and the ligand was done by physical methods like elemental analysis, UV-VIS spectra, ${ }^{1} \mathrm{H}-\mathrm{NMR}$, IR and conductance studies. Additionally, the thermal degradation pattern was examined by TG/DT analysis. Antimicrobial activities are studied with both gram negative Pseudomonas aeruginosa, Salmonella typhi, Eschericia coli and gram positive bacteria Bacillus subtilus, Staphylococcus aureus, Staphylococcus epidermis, Streptococcus pneumonia.
\end{abstract}

Key Words: $N$-[(E)-pyridin-3-ylmethylidene]benzenesulfonamide (PMBS), Escherichia coli, Salmonella typhi, Bacillus subtilus, Staphylococcus aureus.

\section{INTRODUCTION}

Sulfonamide derivatives form a scaffold in a number of pharmacologically active compounds. Their toxicity is attributed to $\mathrm{SO}_{2} \mathrm{NH}$ moiety. Among the pharmacological properties, antibacterial is the most important one. Sulfonamides inhibit the biosynthesis of tetrahydrofolate in the bacteria, which is a co-factor for the bacterial DNA and RNA synthesis. Deficiency of tetrahydrofolate, decreases the production of new DNA and RNA, ultimately resulting in the bacterial decay. Sulfonamides mimic the substrate for the enzymes and thus block their active sites by reacting with them first instead of the substrate ${ }^{1}$. Human carbonic anhydrase inhibitors which are potential antitumor agents, are characterized by the sulfonamide units². They are classified as chemotherapeutic agents.

Sulfonamides are used in the treatment of the diseases like glaucoma, epilepsy, congestive heart failure, mountain sickness, gastric and duodenal ulcers $^{2}$. Its derivatives are used as antifungal, anti-inflammatory and hypoglycemic agents ${ }^{3}$. Ligands based on the sulfonamides are used as asymmetric catalysts ${ }^{4}$. Metal complexes modify the pharmacology and toxicology of the sulfonamide based ligands ${ }^{5}$.

The present work is based on the antibacterial properties of a novel aromatic sulfonamide derivative i.e $N-[(E)$-pyridin-3-ylmethylidene $]$ benzenesulfonamide (PMBS) and its corresponding first row transition metal complexes i.e $\mathrm{Cu}(\mathrm{II}), \mathrm{Co}(\mathrm{II})$ and $\mathrm{Zn}(\mathrm{II})$.

\section{EXPERIMENTAL}

Materials and methods

Solvents used were of analytical grade. Common solvents were distilled twice before use. Metal (II) chlorides used were obtained from Riedel-deHaen, Germany. The pyridine-3-carbaldehyde and benzene sulfonamide were of analytical grade obtained from Acros Organics, USA and used without further purification.

\section{Instrumentation}

The compounds weight was determined on Ohaus, AR 2140(USA), digital balance. Melting points were recorded on a Gallen kamp (UK) apparatus. Conductivity meter type AGB 1000 was used to measure the complexes conductivities ${ }^{6}$. The magnetic moments of the solid complexes were determined by the Gouy's method at room temperature using $\mathrm{Hg}\left[\mathrm{Co}(\mathrm{SCN})_{4}\right]$ as a standard ${ }^{7}$. Ultraviolet and visible absorption spectra of the complexes in the range $300-1000 \mathrm{~nm}$ in different solvents were obtained on a BMS UV-1602. The Infrared spectra of the ligands and solid complexes were run on a Shimadzu FTIR spectrophotometer. Proton NMR spectra of the ligand was recorded on a Bruker (AM400) spectrometer. The spectra were measured in DMSO-d

Biological studies

The ligand and its complexes were tested against both gram positive and gram negative bacteria. Gram positive included Bacillus subtilus, Staphylococcus aureus, Staphylococcus epidermis, Streptococcus pneumonia while Pseudomonas aeruginosa, Salmonella typhi, Eschericia coli represented gram negative bacteria. Imipenem was used as a standard drug. It belongs to the carbapenem class of compounds, which are used as a last shot against many infectious bacteria ${ }^{8}$. The activity was measured by comparing the zones of inhibition. Zones of inhibition correspond to the area where bacteria were killed by using the standard drug, the ligand and the respective complexes. They were measured in diameter $(\mathrm{mm})$. A concentration of $1 \mathrm{mg} / 6 \mu \mathrm{L}$ was used to carry out the different antibacterial activities.

Preparation of ligand

0.02 moles of pyridine-3-carbaldehyde dissolved in methanol were mixed with a methanolic solution of 0.02 moles of benzene sulfonamide at room temperature. The product appeared after 2 minutes. The reaction was monitored by TLC. The precipitate formed was separated through a sintered glass crucible, washed with dichloromethane and then dried in a vacuum oven. M.P. $100-112^{\circ} \mathrm{C}$, Color $=$ Yellowish white, Yield $=33 \%$.

(PMBS)<smiles>O=Cc1cccnc1</smiles>

pyridine-3-carbaldehyde

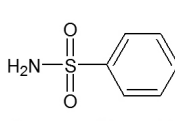

benzenesulfonamid

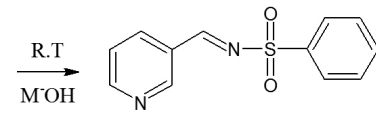

$N-[(E)$-pyridin-3-ylmethylidene]benzenesulfonamide

\section{Scheme I: Preparation of PMBS}

\section{Preparation of complexes}

The complexes were prepared by the following general method. 0.01 moles of the corresponding metal (II) chloride was dissolved in a minimum amount of dry ethanol. The moisture was removed by stirring with 2 , 2-dimethoxypropane for one hour, followed by the addition of an ethanolic ligand solution $(0.01 \mathrm{~mole})$. The mixture was stirred for one hour. Crystals were separated by evaporating the solvent under vacuum. Recrystallization was carried out with dichloromethane. The general synthetic procedure is described on scheme II.

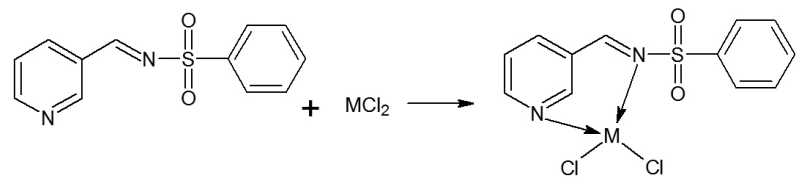

Scheme II: Complex(s) Preparation

$\mathrm{M}=\mathrm{Co}(\mathrm{II}), \mathrm{Cu}(\mathrm{II}), \mathrm{Zn}(\mathrm{II})$

\section{RESULT AND DISCUSSION}

The ${ }^{1} \mathrm{H}$ NMR spectra of only the Schiff base was determined in DMSO-d. The ligand exhibited signals that have been identified from the integration curve and found to be equivalent to the total number of protons deduced from its proposed structures. Peak at $10.01 \mathrm{ppm}$ is assigned to azomethine hydrogen $\mathrm{H} 10$. Peak at $8.90 \mathrm{ppm}$ is assigned to the $\mathrm{H} 1$, peak at 9.1 shows $\mathrm{H} 4$, small peaks 


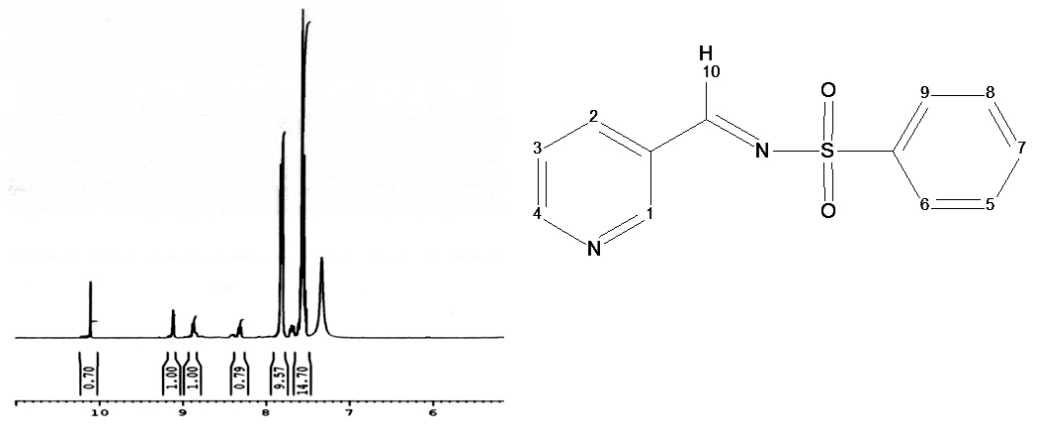

Fig.1 ${ }^{1} \mathrm{H}$ NMR Spectra of PMBS in DMSO-d ${ }^{6}$

The ligand shows prominent peaks at $1473 \mathrm{~cm}^{-1}(\mathrm{Py}-\mathrm{N}), 1635 \mathrm{~cm}-1(\mathrm{C}=\mathrm{N}), 1319 \mathrm{~cm}^{-1}(\mathrm{O}=\mathrm{S}=\mathrm{O})$. $\left[\mathrm{Co}(\mathrm{PMBS}) \mathrm{Cl}_{2}\right]$ shows a shift in the peaks of Py-N $\left(1446 \mathrm{~cm}^{-1}\right)$ and $\mathrm{C}=\mathrm{N}\left(1645 \mathrm{~cm}^{-1}\right)$ Table 2. reflecting that the ligand coordinated through nitrogen atoms of the pyridine and azomethine. The data for the rest of complexes is also given in Table 2 ,

Table 1 Analytical Data of PMBS Ligand and its Metal (II) Complexes.

\begin{tabular}{|c|c|c|c|c|c|c|c|c|c|c|c|c|c|}
\hline \multirow{2}{*}{ S. No } & \multirow{2}{*}{ Compound } & \multirow{2}{*}{ Color } & \multirow{2}{*}{ M.P ${ }^{\circ} \mathbf{C}$} & \multicolumn{2}{|c|}{$\% \mathrm{C}$} & \multicolumn{2}{|c|}{$\% \mathrm{H}$} & \multicolumn{2}{|c|}{$\% \mathrm{~N}$} & \multicolumn{2}{|c|}{$\%$ Cation } & \multicolumn{2}{|c|}{$\%$ Anion } \\
\hline & & & & Cal & Found & Cal & Found & Cal & Found & Cal & Found & Cal & Found \\
\hline 1 & PMBS & $\begin{array}{c}\text { Yellowish } \\
\text { white }\end{array}$ & $100-112$ & 58.52 & 58.49 & 4.09 & 4.06 & 11.37 & 11.21 & - & - & - & - \\
\hline 2 & {$\left[\mathrm{Co}(\mathrm{PMBS}) \mathrm{Cl}_{2}\right]$} & Violet & $194-200$ & 38.32 & 38.31 & 2.68 & 2.66 & 7.45 & 7.50 & 15.67 & 15.47 & 18.85 & 18.81 \\
\hline 3 & {$\left[\mathrm{Cu}(\mathrm{PMBS}) \mathrm{Cl}_{2}\right]$} & Green & $160-165$ & 37.86 & 37.77 & 2.65 & 2.56 & 7.36 & 7.24 & 16.69 & 16.52 & 18.62 & 18.48 \\
\hline 4 & {$\left[\mathrm{Zn}(\mathrm{PMBS}) \mathrm{Cl}_{2}\right]$} & White & $120-122$ & 37.67 & 37.61 & 2.63 & 2.59 & 7.32 & 7.26 & 17.10 & 17.07 & 18.53 & 18.50 \\
\hline
\end{tabular}

Table 2 IR Data of Ligand PMBS and its Metal (II) Complexes.

\begin{tabular}{|c|c|c|c|c|}
\hline S.No & Compound & $(\mathbf{P y}-\mathbf{N}) \mathbf{v} \mathbf{~ c m}^{-\mathbf{1}}$ & $(\mathbf{C}=\mathbf{N}) \mathbf{v} \mathbf{~ c m}^{-\mathbf{1}}$ & $(\mathbf{O}=\mathbf{S}=\mathbf{O}) \mathbf{v} \mathbf{~ c m}^{-\mathbf{1}}$ \\
\hline 1 & PMBS & 1473 & 1635 & 1319 \\
\hline 2 & {$\left[\mathrm{Co}(\mathrm{PMBS}) \mathrm{Cl}_{2}\right]$} & 1446 & 1645 & 1330 \\
\hline 3 & {$\left[\mathrm{Cu}(\mathrm{PMBS}) \mathrm{Cl}_{2}\right]$} & 1429 & 1680 & 1325 \\
\hline 4 & {$\left[\mathrm{Zn}(\mathrm{PMBS}) \mathrm{Cl}_{2}\right]$} & 1444 & 1610 & 1334 \\
\hline
\end{tabular}

Table 3 Conductance, Magnetic andSpectral Data for Complexes of PMBS.

\begin{tabular}{|c|c|c|c|c|c|c|}
\hline \multirow{2}{*}{ S. No } & \multirow{2}{*}{ Complex } & Solvent & $\begin{array}{l}\text { Molar conductance } \\
(\mathrm{mS}) \mathrm{mol}^{-1}\end{array}$ & $\mu$ eff (B.M) & $\lambda \max$ & Energy \\
\hline & & & & & $(\mathrm{nm})$ & $\left(\mathrm{cm}^{-1}\right)$ \\
\hline 1 & {$[\mathrm{Co}(\mathrm{PMBS})] \mathrm{Cl}_{2}$} & DMF & 29.7 & 4. 1 & $\begin{array}{l}601 \\
670\end{array}$ & $\begin{array}{l}16638 \\
14925\end{array}$ \\
\hline 2 & {$[\mathrm{Cu}(\mathrm{PMBS})] \mathrm{Cl}_{2}$} & DMF & 0.75 & 1.2 & 622 & 16077 \\
\hline 3 & {$\left[\mathrm{Zn}(\mathrm{PMBS}) \mathrm{Cl}_{2}\right]$} & DMF & 4.28 & Diamagnetic & & \\
\hline
\end{tabular}

The close agreement between the calculated and found values of the elemental analysis results shows the formation of PMBS, Table 1. In the same Table 1 the analytical data of the complexes are shown, corroborating the general formula of $\mathrm{M}(\mathrm{PMBS}) \mathrm{Cl}_{2}$ for all of them. $\%$ anion and cations were calculated using standard volumetric method ${ }^{9}$.

The molar conductance of $\mathrm{Co}(\mathrm{II}), \mathrm{Cu}(\mathrm{II})$ and $\mathrm{Zn}(\mathrm{II})$ complexes are reported in Table 3. The molar conductance values indicate that they are all non-electrolytic in nature. In non-electrolytic complexes the anion is bonded to the metal and therefore is present within the coordination sphere while in electrolytic complexes the anion remains outside the coordination sphere ${ }^{10},{ }^{11},{ }^{12},{ }^{13}$ Table 3.

The magnetic moment value for Co(II) complex is 4.1 B.M, indicating the presence of three unpaired electrons. The magnetic moment value of $\mathrm{Cu}(\mathrm{II})$ complex is 1.2 B.M, which show the presence of one unpaired electron. The
$\mathrm{Zn}$ (II) complex has no magnetic moment indicating a diamagnetic character Table 3.

$\left[\mathrm{Co}(\mathrm{PMBS}) \mathrm{Cl}_{2}\right]$ exhibited well resolved peak at $16638 \mathrm{~cm}^{-1}(601 \mathrm{~nm})$ and assigned to ${ }^{4} \mathrm{~A}_{2} \rightarrow{ }^{4} \mathrm{~T}_{1}(\mathrm{~F})$ and at $14925 \mathrm{~cm}^{-1}(670 \mathrm{~nm})$ is assigned to ${ }^{4} \mathrm{~A}_{2}$ $\rightarrow{ }^{4} \mathrm{~T}_{1}(\mathrm{P})^{14}$.These values supports the tetrahedral geometry for $\mathrm{Co}$ (II) complex. In $\left[\mathrm{Cu}\right.$ (PMBS)Cl] the peak is at $16077 \mathrm{~cm}^{-1}(622 \mathrm{~nm}) \mathrm{Fig.3}$ and is assigned to the transition ${ }^{2} \mathrm{~B}_{2} \rightarrow{ }^{2} \mathrm{~A}_{1}$. The low absorption value is because of the dilute solution that we used to carry out the spectra. These observations support the tetrahedral geometry of $\mathrm{Cu}(\mathrm{II})$ complex. The $\left[\mathrm{Zn}\left(\mathrm{PMBCl}_{2}\right]\right.$ is diamagnetic and is suggested to have tetrahedral geometry ${ }^{15},{ }^{16}$ Table 3 . 


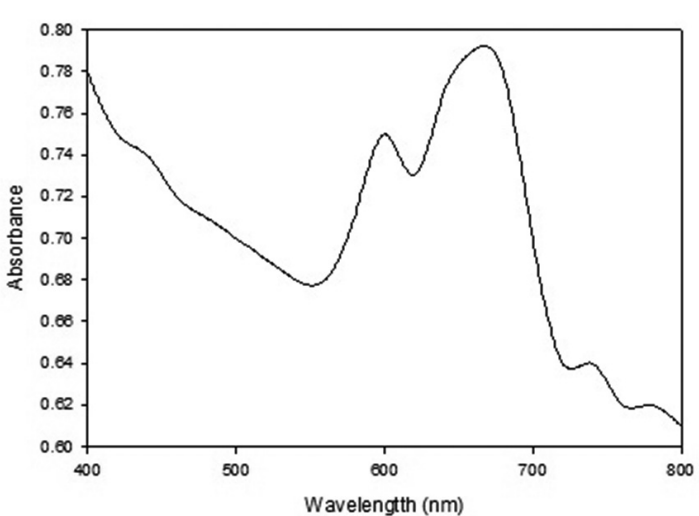

Fig.2 UV-Vis Spectrum for $\mathrm{Co}(\mathrm{PMBS}) \mathrm{Cl}_{2}$ in DMF.

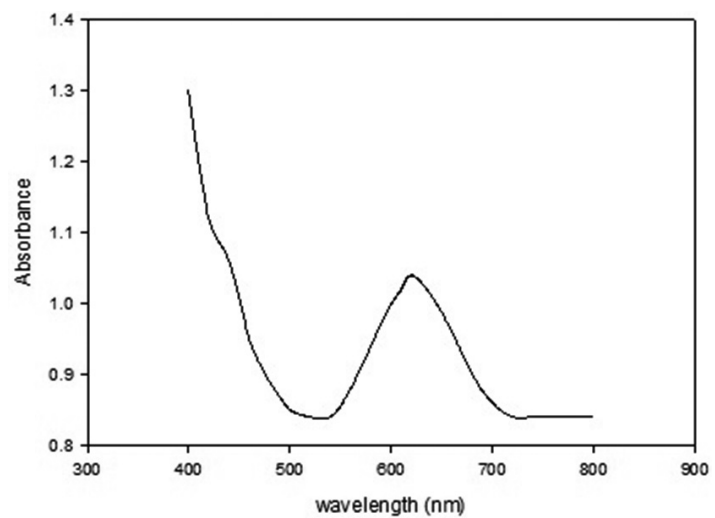

Fig.3 UV-Vis Spectrum for $\mathrm{Cu}(\mathrm{PMBS}) \mathrm{Cl}_{2}$ in $\mathrm{DMF}$.

Table 4 Thermoanalytical Data of Ligand PMBS and its Metal (II) Complexes.

\begin{tabular}{|c|c|c|c|c|c|c|c|}
\hline \multirow{2}{*}{ S. No } & \multirow{2}{*}{ Compounds } & \multirow{2}{*}{$\begin{array}{c}\text { DTA Peak Temp/ } \\
{ }^{\circ} \mathrm{C}\end{array}$} & \multirow{2}{*}{$\underset{/{ }^{\circ} \mathrm{C}}{\mathrm{TG} \text { Temp range }}$} & \multicolumn{2}{|c|}{ Weight loss/mg } & \multirow{2}{*}{ Products Evolved/ Residue } & \multirow[b]{2}{*}{ \%Weight Los } \\
\hline & & & & Calc. & Found & & \\
\hline 1 & PMBS & $150(+)$ & $30-890$ & 6.1 & 6.2 & $\mathrm{C}_{12} \mathrm{H}_{10} \mathrm{~N} 2 \mathrm{SO}_{2}+\mathrm{H}_{2} \mathrm{O}$ & 90 \\
\hline 2 & {$\left[\mathrm{Co}(\mathrm{PMBS}) \mathrm{Cl}_{2}\right]$} & $150(+)$ & $\begin{array}{c}30-1000 \\
1000\end{array}$ & $\begin{array}{l}6.7 \\
1.6\end{array}$ & $\begin{array}{l}6.7 \\
1.6\end{array}$ & $\begin{array}{c}\mathrm{C}_{12} \mathrm{H}_{10} \mathrm{~N}_{2} \mathrm{SO}_{2}+\mathrm{Cl}_{2} \\
\mathrm{CoO} \text { (residue) }\end{array}$ & $\begin{array}{l}80 \\
19\end{array}$ \\
\hline 3 & {$\left[\mathrm{Cu}(\mathrm{PMBS}) \mathrm{Cl}_{2}\right]$} & $550(+)$ & $\begin{array}{c}30-600 \\
600-1000\end{array}$ & $\begin{array}{l}5.4 \\
1.3\end{array}$ & $\begin{array}{l}5.8 \\
0.7\end{array}$ & $\begin{array}{c}\mathrm{C}_{12} \mathrm{H}_{10} \mathrm{~N}_{2} \mathrm{SO}_{2}+\mathrm{Cl}_{2} \\
\mathrm{CuO} \text { (residue) }\end{array}$ & $\begin{array}{l}89 \\
11\end{array}$ \\
\hline 4 & {$\left[\mathrm{Zn}(\mathrm{PMBS}) \mathrm{Cl}_{2}\right]$} & $700(-)$ & $\begin{array}{c}30-735 \\
735-1000\end{array}$ & $\begin{array}{l}6.3 \\
1.6\end{array}$ & $\begin{array}{l}7.1 \\
0.5\end{array}$ & $\begin{array}{c}\mathrm{C}_{12} \mathrm{H}_{10} \mathrm{~N}_{2} \mathrm{SO}_{2}+\mathrm{Cl}_{2} \\
\mathrm{ZnO} \text { (residue) }\end{array}$ & $\begin{array}{c}94 \\
6\end{array}$ \\
\hline
\end{tabular}

Temp $=$ Temperature, Calc.$=$ Calculation,$(+)=$ Endothermic and $(-)=$ Exothermic.

Thermoanalytical study

The ligand PMBS follows a single step degradation process after the loss of a water molecule. The entire ligand is released in the temperature range of $30-890^{\circ} \mathrm{C}$ with an endothermic DTA peak at $150^{\circ} \mathrm{C}$.

All the complexes also follow the same two steps by liberating the ligand in the first step along with the chlorine molecule. Metal oxides (MO) were left as residues in all the complexes, Table 4 . The above degradation pattern can be summarized in the following general equations.

PMBS $\rightarrow \mathrm{H}_{2} \mathrm{O}+\mathrm{PMBS}$

\section{$\mathrm{M}(\mathrm{PMBS}) \mathrm{Cl}_{2} \rightarrow \mathrm{PMBS}+\mathrm{Cl}_{2}$}

$\mathrm{M}+\mathrm{O}_{2} \rightarrow \mathrm{MO}$

\section{Pharmacological Studies}

Ligand PMBS show moderate activities against all the bacterial strains. DMSO was used as a solvent to check their antibacterial activity against the gram negative bacteria Escherichia coli, Salmonella typhi and Pseudomonas aeruginosa and gram positive bacteria Bacillus subtilus, Staphylococcus aureus, Staphylococcus epidermidis, Streptoccus pneumonia Fig. 4. The potency of some of the coordinated compounds is higher than the one observed for the ligand. The toxicity of the coordinated compounds can be explained by the Chelation theory. According to this theory the polarity of the metal ion decreases because of the following two factors.

1. Overlap of the ligand orbitals with the metal orbitals

2. Partial sharing of the positive charge of the metal ion with the donor groups.

These factors help in the delocalization of the n-electrons over the whole chelate ring and thus increase the lipophilic character of the complexes. This increased lipophilicity renders high penetration to the complexes into the bacterial system, thus blocking the metal binding sites of the specific enzyme ${ }^{17}$. So this chelation theory explains the high activity of the complexes as compared to the uncomplexed ligand. Zinc complex was most active against Bacillus subtilus, Staphylococcus epidermis, Salmonella typhi showing $80 \%$, $58 \%$ and $60 \%$ activity. The rest of the complexes were either moderately or weakly active.

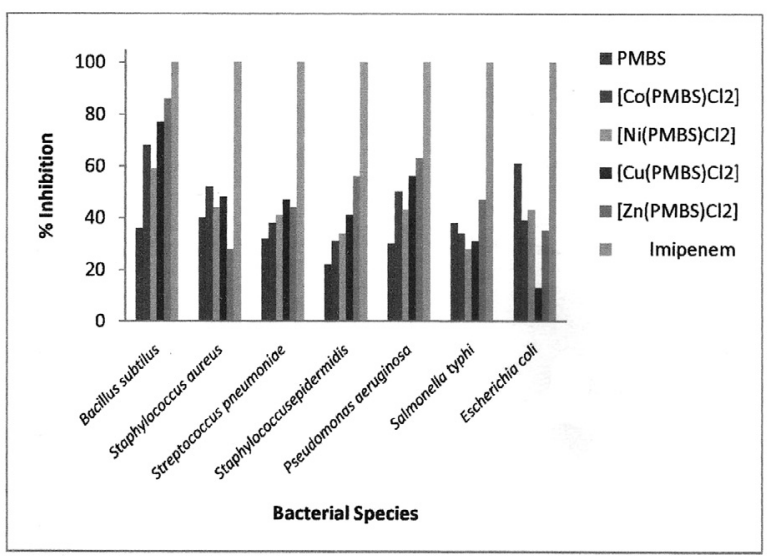

Fig.4 Antibacterial Activities of PBMS and its Metal (II) Complexes.

\section{CONCLUSION}

The novel sulfonamide derivative $N$ - $[(\boldsymbol{E})$-pyridin-3-ylmethylidene] benzenesulfonamide was synthesized and characterized by ${ }^{1} \mathrm{H}-\mathrm{NMR}$, IR and elemental analysis. Its transition metal complexes were also synthesized and properly characterized. The thermal study that we carried out suggested that new bonds have been formed in the complexes i.e between the ligand and the transition elements because the degradation pattern seen in the ligand got changed in case of the complexes. The antibacterial activity shows that zinc complex was most active against Bacillus subtilis exhibiting more than $80 \%$ activity. The rest of the compounds were moderately active. 


\section{ACKNOWLEDGEMENT}

We are really grateful to HEJ Research Institute of Chemistry, University of Karachi, Karachi Pakistan for elemental analysis and ${ }^{1} \mathrm{H}-\mathrm{NMR}$. Bioactivity was done by the courtesy of Department of Biotechnology, University of Peshawar, Peshawar, Pakistan.

\section{REFERENCES}

1. Claudiu T.Supuran, F. B., Silvia Tilli, W. Richard Chegwidden, Andrea Scozzaffava, Carbonic Anhydrase Inhibitors: Sulfonamides as Antitumor Agents. Bioorganic and Medicinal Chemistry 2001, 9, 703-714.

2. Hitchings, G. H., Mechanism of Action of TrimethoprimSulfamethoxazole-I. Journal of Infectious Diseases 1973, 128 (Suppl. 3), S433-S436.

3. Jaume Balsells, P. J. W., Asymmetric Cyclopropanation of Allylic Alcohols Employing Sulfonamide/Schiff Base Ligands. Journal of Organic Chemistry 2000, 65, 5005-5008.

4. M. A. Neelakantan, M. E., S. S. Mariappan, J. Dharmaraja, T. Jeyakumar, Synthesis, Characterization and Biocidal Activities of Some Schiff Base Metal Complexes. Indian Journal of Pharmaceutical Sciences 2010, 72 (2), 216-222.

5. Zahid H.Chohan, H. A. S., Sulfonamide derived compounds and their transition metal complexes: synthesis, biological evaluation and $\mathrm{x}$-ray structure of 4-bromo-2-[(E)-\{4-[3,4-dimethylisoxazol-5yl)sulfamyl] phenyl \}iminiomethyl] phenolate. Applied Oranometallic Chemistry 2011, 25, 591-600.

6. Porwal, S.; Kumar, R.; Prakas, R. M.; Prem, M. S.; Chauhan, A multicomponent reaction efficiently producing arylmethylene 2-thiohydantoins. Tetrahedron Letters 2006, 47, 5863.
7. Figgis, B. N.; Lewis, j.; Willikins, R. G., Modern Inorganic Chemistry. Inter science Inc: New York, 1960; p 412.

8. Amirmorteza Ebrahimzadeh Namver, B. A., Shoshtari Zadeh, Abdolaziz Rastegar Lari, Comparison of in vitro activity of imipenem productions on bacterial isolates from Hashemi Nezhad Tehran hospitalized patients. Journal of Bacteriology Research 2010, 2 (5), 51-54.

9. Vogel, A. I., Vogel's Textbook of Quantitative Chemical Analysis. 5th ed.; English Language Book Society/ Longman: London, 1939.

10. Carlin, R. L., Transition metal chemistry. Marcel Dekker,: New York, $1965 ; \mathrm{p} 243$.

11. W.E. Estes, D. P. G., W.B. Halfield, D.J. Hodgson, , Inorganic Chemistry 1978, 17,1415

12. Shoemaker, D. P.; Greenland, C. W., Experiments in Physical Chemistry. McGraw-Hill. Book Co.Inc: New York, 1962; p 196.

13. Danials, F.; Williams, J. W.; Bender, P.; Alberty, P. A.; Cornwell, C. D., Experimental Physical Chemistry. McGraw- Hill: New York, 1962; p 158,473 .

14. S B Kalia, K. L., G Kausal, M Sharma, Magnetic and spectral studies on cobalt(II) chelates of a dithiocarbazate derived from isoniazid. Indian journal of Chemistry 2007, 46 (A), 1233-1239.

15. Figgis, B. N.; Nyholm, R. S., A Convenient Solid for Calibration of the Guoy Magnetic Susceptibilty Apparatus. J.Chem.Soc 1958, 4190.

16. Lever, A. B. P., Inorganic electronic spectroscopy. Elsevier: Amsterdam, 1984; $\mathrm{p} 210$.

17. (a) Baluja, S.; Solanki, A.; Kachhadia, N., Evaluation of Biological Activities of Some Schiff Bases and Metal Complexes. Journal of the Iranian Chemical Society 2006, 3 (4), 312-317; (b) Mishra, L.; Singh, V. K., $\mathrm{Co}(11), \mathrm{Ni}(11)$ and $\mathrm{Cu}(\mathrm{II})$ and $\mathrm{Zn}(\mathrm{II})$ complexes with Schiff bases derived from 2-aminobenzimidazoles and pyrazolycarboxaldehyde. Ind. J. Chem. 1993, 32A 446. 